\title{
Anna Ledwina
}

aledwina@uni.opole.pl

orcid.org/0000-0002-5054-1775

Uniwersytet Opolski

Instytut Kultury i Języka Francuskiego

pl. Kopernika 11

45-040 Opole

\section{Od buntu do wyzwolenia.} Image kobiety nieobyczajnej według Sidonie-Gabrielle Colette, Simone de Beauvoir, Françoise Sagan i Marguerite Duras

From Rebellion to Liberation: The Image of an III-Mannered Woman in the Literary Works of Sidonie-Gabrielle Colette, Simone de Beauvoir, Françoise Sagan and Marguerite Duras

Summary: A woman's identity, including her sexuality, reflects, as it were, her struggle for freedom within the domestic sphere, throughout history and culture, and charts her route to emancipation. In the context of cultural, moral, and ethical facts inspired by the theory of gender, the aim of the paper is to set forth a reflection on the question of the figure of the transgressive woman in French literature of the $19^{\text {th }}$ and $20^{\text {th }}$ centuries. This issue is viewed in relation to the sphere of the author's personal life, as well as taking into account the historical and anthropological perspective related to the specificity and mentality of $19^{\text {th }}$ and $20^{\text {th }}$ century France; in particular, the social and public roles assumed by women yet imposed on them by society. Literary works by Sidonie-Gabrielle Colette, Simone de Beauvoir, Françoise Sagan, and Marguerite Duras depict the picture of the modern woman, freed from the tight corset of etiquette, aware of her self-esteem, transgressing sexual taboos, 
and debunking fixed social and literary stereotypes. The research strategy adopted in this paper aims to utilize a considerably broad observational field, making it possible to present the above issues from a comparative perspective. From such a perspective, the picture of a woman contesting the fixed standards of the obedient wife and mother appears as a multi-level issue showing the complexity of her nature and an abundance of factors conditioning the female ego, who ultimately evolves from an initial aversion to bourgeois morality to an outright revolt manifesting itself through non-standard or even scandalous behaviour.

Keywords: identity, contestation, transgression, morality, stereotypes, modern woman

Streszczenie: Tożsamość (także płciowa) kobiety w przestrzeni domu, w historii, kulturze i na drogach emancypacji odzwierciedla niejako jej walkę o wolność. W kontekście faktów kulturowych, obyczajowych i etycznych inspirowanych przez teorię gender niniejszy artykuł ma na celu refleksję nad kwestią obrazu kobiety transgresywnej w literaturze francuskiej XX w. Zagadnienie to rozpatrywane jest $w$ odniesieniu do sfery jej życia osobistego oraz przyjmowanych przez nią określonych ról społecznych i publicznych, przy uwzględnieniu perspektywy historycznej i antropologicznej, związanej ze specyfiką oraz mentalnością Francji XX stulecia. Spod pióra Sidonie-Gabrielle Colette, Simone de Beauvoir, Françoise Sagan oraz Marguerite Duras wyłania się wizerunek kobiety nowoczesnej, wyzwolonej z ciasnego gorsetu konwenansów, świadomej swojej wartości, przekraczającej seksualne tabu, demaskującej utrwalone stereotypy społeczne i literackie.

Zastosowana strategia badawcza pozwoliła na zakreślenie w miarę szerokiego pola obserwacji, umożliwiającego przedstawienie problematyki w ujęciu komparatystycznym. Dzięki temu obraz kobiety kontestującej utrwalone wzorce posłusznej żony i matki jawi się wieloaspektowo, z różnych punktów widzenia, ukazując złożoność jej natury oraz całe bogactwo czynników warunkujących kobiece ja, które ewoluuje od niechęci w stosunku do mieszczańskiej moralności do buntu przejawiającego się poprzez nienormatywne czy wręcz skandalizujące zachowania.

Słowa kluczowe: tożsamość, kontestacja, transgresja, obyczajność, stereotypy, nowoczesna kobieta 
Od buntu do wyzwolenia. Image kobiety nieobyczajnej... From Rebellion to Liberation: The Image of an III-Mannered Woman...

Szeroko rozumiana tematyka kobieca, obecna szczególnie w literaturze tworzonej przez kobiety w ujęciu kulturowo-antropologicznym, wzbudza coraz większe zainteresowanie czytelników i badaczy. Wprowadzenie terminu płci kulturowej gender - pozwoliło zrozumieć, że status kobiet, ich uzależnienie od mężczyzn nie zostały narzucone przez prawa natury, lecz stanowią konstrukcję społeczną, podlegającą zmianom w relacjach z mężczyznami. Powstające publikacje książkowe, toczone dyskusje na temat roli kobiet, ich kondycji i miejsca w strukturach społecznych rodzą nowe pytania warte refleksji.

Literatura francuska w każdym czasie bywała odbiciem obyczajów i upodobań swojej epoki. Także wXX w. zmiana mentalności w podejściu do kobiet, będąca efektem wojny, jak również rewolucji przemysłowej, stworzyła zupełnie nowe warunki rozwoju literatury kobiecej. Przedmiotem mojej analizy będą powieści znanych pisarek francuskich XX stulecia, w których problem tożsamości kobiety w historii, w przestrzeni prywatnej i publicznej oraz na drogach emancypacji należy do pierwszoplanowych, zwłaszcza w aspekcie interdyscyplinarnym afirmacji wolności oraz zachowań nienormatywnych w każdej dziedzinie życia przez przedstawicielkę „drugiej płci”.

Warto zaznaczyć, że francuskie społeczeństwo mieszczańskie aprobowało normy $i$ konwenanse, według których jedynym uznawanym modelem życia rodzinnego było małżeństwo i macierzyństwo. Kobieta - całkowicie zależna od mężczyzny miała spełnić się wyłącznie jako idealnie posłuszna, wzorowa westalka domowego ogniska. Znaczenie jej określano w odniesieniu do mężczyzny, była jego dopełnieniem, podporą, ozdobą, zabawką, marzeniem lub inspiracją. Ten stan rzeczy wynikał z wykluczenia kobiet jako obywatelek ze sfery publicznej. Pamiętajmy, że kodeks cywilny Napoleona (1804), potwierdzając mizoginizm i antyfeminizm, wzmocnił patriarchalny model społeczeństwa francuskiego, w którym „długo utrzymywał się silny autorytet ojca i męża”" ${ }^{1}$, i pozbawił kobietę możliwości decydowania o sobie. Odstępstwo od przyjętych przekonań naraża na pogardę i ostracyzm społeczny w patriarchalnym świecie, w którym panuje podwójna moralność, wyznaczająca dwóm płciom konkretne role do odegrania. Cała sfera prywatna, w tym seksualność, podlegająca wymogom wychowania i opinii - jak zauważa Michel Foucault ${ }^{2}$ stanowi tabu. Zdaniem wybitnego socjologa Ericha Fromma, „moralność stała się niemal tożsama z moralnością seksualną i cnotą, z przestrzeganiem zakazów seksualnych, narzuconych przez kulturę. [...] Kwestie etyki przesłoniło przekonanie, że "ciało» jest źródłem zła" biety w Trzeciej Republice (1870-1940) odnajdzie czytelnik w książce francuskiego historyka Jules’a Micheleta La Femme (1981), przedstawiającej różne aspekty życia i roli kobiety, postrzeganej jako istota działająca destrukcyjnie, pozbawiona mocy

\footnotetext{
1 M. Bogucka, Gorsza płeć. Kobieta w dziejach Europy od antyku po wiek XXI, Wydawnictwo Trio, Warszawa 2005, s. 262.

2 M. Foucault, Historia seksualności, tłum. B. Banasiak, T. Komendant, Czytelnik, Warszawa 2000, s. 13-21.

3 E. Fromm, Miłość, płeć i matriarchat, tłum. B. Radomska, G. Sowiński, Dom Wydawniczy Rebis, Poznań 1997, s. 145-146.
} 
kreatywnej, stworzona do posłuszeństwa i miłości, utożsamiana z wzorową panią domu o wielkim sercu, której wartość określa macierzyństwo. Zupełnie inny obraz kobiety kreśli (w La Française et la France, 1951) Jean Giraudoux - francuski intelektualista, dyplomata, XX-wieczny dramaturg, który widział w niej zmienniczkę mężczyzny, osobę zbuntowaną, potrafiącą rozwiązywać problemy, dopełniającą mężczyznę dzięki swemu instynktowi, niezwykle cenną dla społeczeństwa.

Sidonie-Gabrielle Colette, Simone de Beauvoir, Françoise Sagan, Marguerite Duras to powieściopisarki, które przeciwstawiły się tradycyjnemu wizerunkowi kobiety i mitycznemu myśleniu o niej jako o istocie pozbawionej wszelkich praw, wywierając ogromny wpływ na obyczajowość swoich czasów. Interesująca wydaje się zatem odpowiedź na pytanie, w jaki sposób autorki obaliły mit słabej kobiety, przyczyniając się do modelowania kobiety nowoczesnej i nieobyczajnej. Podejmę próbę ukazania wzorca kobiecości wykreowanego przez pisarki - cech, fantazji oraz aspiracji ich bohaterek - a przez to znaczenia tej prozy dla rozwoju współczesnej myśli socjologicznej.

W moich rozważaniach odwołam się do stanowiska prezentowanego przez Élisabeth Badinter ${ }^{4}$, francuską badaczkę, która zestawiła stereotyp kobiecy i męski, biorąc pod uwagę stabilność emocjonalną, autonomię, mechanizmy kontroli, dominację, agresywność, poziom aktywności, cechy intelektualne, kreatywność, seksualność. Antropolożka ta zwraca uwagę na zakorzeniony w świadomości tradycyjny obraz kobiety kapryśnej, wrażliwej, niezdecydowanej, bojaźliwej, uczuciowej, histerycznej, frywolnej, naiwnej. Pod względem mechanizmów kontroli kobietę charakteryzują gadatliwość, zmanierowanie, tajemniczość, upór. Jeśli chodzi o kwestię zależności i autonomii, postawa kobiety prezentuje potrzebę zwierzania się, podobania i podporządkowania. W świetle tych stwierdzeń uzasadnione wydaje się postawienie pytań, jaki portret kreślą francuskie powieści XX w., jakie cechy dominują w naturze kobiecej i w jaki sposób kształtowały one obyczajowość epoki.

W niniejszym artykule ograniczę się do ukazania reprezentatywnego wizerunku kobiety wyzwolonej, przekraczającej normy moralne, który wyłania się spod pióra wnikliwych obserwatorek, demaskując utrwalone stereotypy społeczne i literackie. Znakomitym przykładem ilustrującym takie zachowanie jest bez wątpienia protagonistka cyklu Klaudyn (1900-1903) - owianego skandalem debiutu literackiego Colette, stanowiącego nowatorską wizję dokonujących się zmian w obyczajowości na początku XX stulecia. W wieku kilkunastu lat Klaudyna świadoma jest swojego uroku i możliwości uwodzenia, podobnie jak jej rówieśniczki:

trzynastoletnie dziewuszki, o figurce już uformowanej i łydkach okrągłych, nadużywały niecnie tego, co nazywamy przywilejami dzieciństwa. Okrakiem na kolanie dorosłego kuzyna lub też przycupnięte wysoko na stołku przy barze, z kolanami pod brodą, śliczne blondyneczki [...] pokazują, co tylko mogą, i śledzą zimnym wzrokiem kotki, jakie wrażenie robi to na mężczyznach ${ }^{5}$.

4 E. Badinter, L'Un est l'autre. Des relations entre hommes et femmes, Odile Jacob, Paris 1986, s. 165.

5 S.-G. Colette, Klaudyna w szkole, tłum. K. Dolatowska, PIW, Warszawa 1958, s. 72. 
Od buntu do wyzwolenia. Image kobiety nieobyczajnej... From Rebellion to Liberation: The Image of an III-Mannered Woman...

Klaudyna, jednocześnie nieśmiała i samodzielna młoda dziewczyna, reprezentuje jeden z ulubionych typów bohaterek Colette - kobietę niewiniątko - który kojarzył się z żywiołem erotyzmu. To - według określenia Herberta Lottmana $^{6}$ postać „grzeszna, czarująca i uniwersalna”. Frywolna, pełna wdzięku i dziewczęcej naiwności, prowokuje mężczyzn, otwarcie wyznając: „wszystko mi się podoba, trochę za bardzo nawet. Dobrze jest nie wiedzieć najpierw i uczyć się potem, śmiać się nerwowo, krzyczeć i wydawać zduszone jęki [...]" ${ }^{\prime \prime}$. Jest ona obrazem epoki, w której żyje, „z natury skłonna do perwersji, egoistka, pozbawiona wszelkiego zmysłu moralnego [...]" ${ }^{\prime \prime}$. Pikantna proza skandalistki belle époque eksponuje zmysłową i bezpruderyjną kobiecość, autentyczność kobiecych pragnień i naturalnych instynktów, odejście od tradycyjnej mieszczańskiej definicji moralności, specyficzny „somatyzm".

Tradycyjny pogląd, zgodnie z którym kobieta staje się bardziej uwodzicielska, gdy przestaje być nastolatką i zdobywa doświadczenie po trzydziestym roku życia, został jednoznacznie obalony. Lisa Chaney zwraca uwagę, że z pozoru powieści o Klaudynie „pełniły rolę soft porno dla burżuazji, ale pod warstewką przyjemnego podniecenia i seksualnej herezji Colette ubierała w słowa niepokojący problem, jaki nękał współczesnych jej Francuzów: walkę płci" . Zauważmy, że stosunek mężczyzn do kobiet był wówczas ambiwalentny. Kobieta postrzegana jako (ziemskie odzwierciedlenie) Wenus była czczona. Jednocześnie fin de siècle przyniósł niepokojące jej wyobrażenie jako femme fatale, sfinksa pożerającego mężczyzn, antywzorzec świętej, niebezpieczny obiekt pożądania lub adoracji, wybijający się na drodze ku złu. W prowokacyjnie wyzbytej konwenansów Klaudynie Colette uchwyciła pewien rys społeczeństwa. Młode kobiety bowiem nie przypominały cocottes, ale urokliwe podlotki, które charakteryzowała zadziorność, anarchistyczna kobiecość, ignorancja, brak onieśmielenia i skrępowania. Pozbawiona ogłady i manier bohaterka była wyzywająca, pewna siebie, buntownicza. Symbolizowała seksualność tamtego okresu, stając się niepokojącym wizerunkiem kobiecości, jak w późniejszym okresie Lolita z powieści Vladimira Nabokova z 1955 r. Wówczas zaczynało być modne upodobanie do niedojrzałej kobiecości, określanej mianem fruits verts (niedojrzały owoc). Autorka - ekstrawagancka modernistka - propagowała kult młodości oraz grę instynktów. Fenomen Klaudyny polegał na wprowadzeniu nowego ideału kobiety o swobodnym sposobie bycia i nieskrępowanych zasadach moralnych, która przeciwstawiała się normom wiktoriańskim. Była to garçonne kobieta inteligentna, która odrzucała także obowiązującą modę, tj. koronki, jedwabie, długie suknie i wielkie kapelusze, preferując strój uczennicy.

\footnotetext{
6 H. Lottman, Colette. Największy skandal Belle Époque, tłum. J. Addeo-Bratkiewicz, Wydawnictwo Alfa, Warszawa 1999, s. 84.

7 S.-G. Colette, Małżeństwo Klaudyny, tłum. K. Dolatowska, PIW, Warszawa 1958, s. 13.

8 Eadem, Klaudyna w szkole, s. 87.

9 L. Chaney, Coco Chanel. Życie intymne, tłum. A. Gralak, A. Sak, Znak, Kraków 2012, s. 58.
} 
Poprzez lżejszy, krótszy ubiór swoją zbuntowaną kobiecość wyraża także inna bohaterka Colette - Kamila w Kotce (1933). Stawia na niezależność, prowadzi samochód, pali papierosy i używa niecenzuralnych słów. Przejmuje inicjatywę, „rzuca rozkazy”10 i dominuje w związku, także na płaszczyźnie seksualnej, ceniąc "częste chwile zmysłowych uniesień" ${ }^{11}$. Nieskrępowana i trochę „dzika”, „drżąca pragnieniem obnażania się"12 ${ }^{12}$ w miłości pociąga męża Alaina, ale bulwersuje go jednocześnie swoim swobodnym zachowaniem. Ta "dziewczyna o nieopanowanych instynktach"13 "pyszni się pięknem swego ciała, zupełnie niepomna wszelkiej wstydliwości” ${ }^{14}$. Charakteryzuje ją „„ście kobiec[a] bezwzględnoś[ć]” ambicj[a]" ${ }^{16}$ oraz "dążność do unicestwienia przeszkód na swej drodze"17. Ma realistyczne podejście do życia: „jej pragnienia nie wybiegały poza granice obecnej doby. Wystarczyło jej spoczywać we wspólnym łożu, tulić się do ciała mężczyzny, oswajać się z jego barwą, kształtami i brutalnością"18.

Podobne zachowanie charakteryzuje bohaterkę Tamy nad Pacyfikiem (1950) Duras. Autorka porusza kwestię poszukiwania własnej tożsamości poprzez uzmysłowienie sobie znaczenia cielesności. Jej protagonistka Zuzanna to „ładna dziewczyna, [która] miała lśniące, zuchwałe oczy, była młodziutka i pewna siebie"19. Namawiana stale przez matkę, by wyjść za mąż za bogatego Chińczyka, dziewczyna zdaje sobie sprawę z konieczności samodzielnego pokierowania swoim życiem. Nieustannie myśli o tym, aby opuścić dom rodzinny i wyzwolić się spod dominacji matki:

była jak dotąd stanowczo zbyt uległa wobec matki. Rzecz najważniejsza to przede wszystkim uwolnić się od matki, która nie potrafi zrozumieć, że w życiu można sobie wywalczyć niezależność i pozycję innymi środkami niż te, jakie sama uważa za słuszne ${ }^{20}$.

W mieście „wkładając niebieską suknię, zrozumiała, że to, co robi, ma wielkie znaczenie, może nawet największe z wszystkiego, co zrobiła dotychczas" ${ }^{\prime 2}$. Ostatecznie „zrezygnowała z czczych marzeń”22 o byciu szczęśliwą i „oddała się młodemu [Janowi] Agosti”"23, a wówczas „ogarnęło ją [...] kojące podniecenie. Leżała

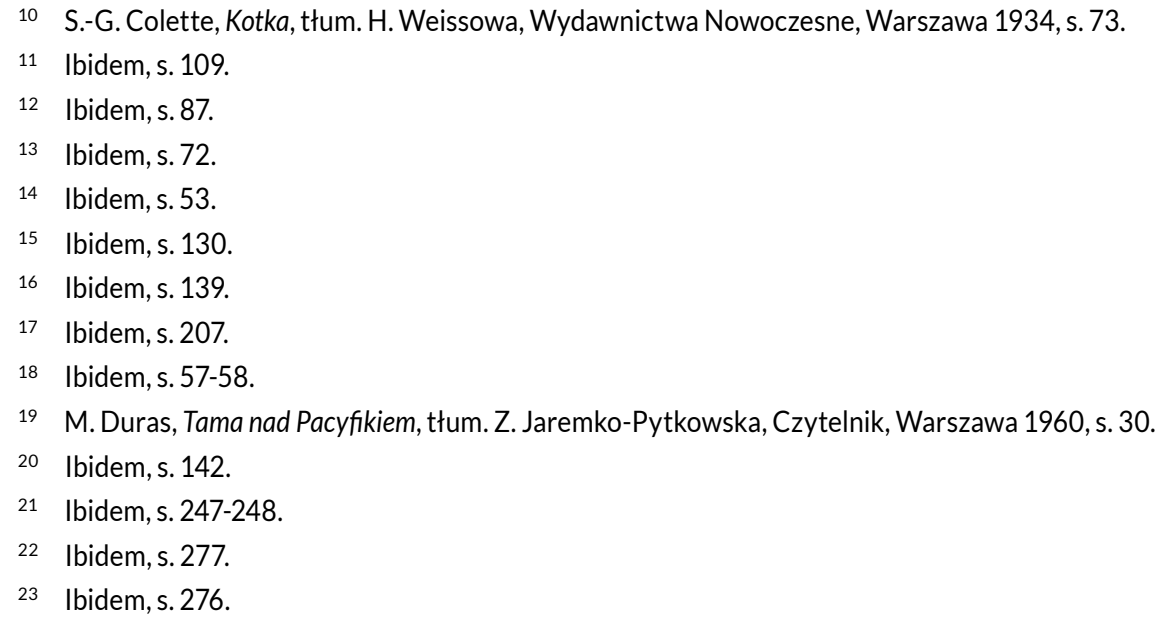


Od buntu do wyzwolenia. Image kobiety nieobyczajnej... From Rebellion to Liberation: The Image of an Ill-Mannered Woman...

rozpogodzona, pełna nowej mądrości” ${ }^{24}$. Zuzanna uświadamia sobie swoją wartość i proponuje jednemu z adoratorów: „Kiedy się wreszcie pobierzemy? [...] zostało już Panu niewiele czasu"25. Młoda kobieta za wszelką cenę poszukuje sensu życia i ucieczki od konwenansów mieszczańskiego środowiska.

Również Kochanek (1984) - najbardziej znana i kontrowersyjna powieść Duras, wyróżniona Nagrodą Goncourtów - zawiera wiele scen, w których uobecnia się kobieca potrzeba autonomii i podmiotowość. Kobietę utożsamia się z cielesnością, seksualnością, a nawet perwersją. Bohaterka przedstawiona jest jako „pani żądzy [mężczyzny], odniesienie intymnych uczuć, [...] mroczna, straszliwa cielesna głębia"26. Piętnastoletnia Francuzka - „wszystkiego ciekawa”27, „taka ładna, [że] może sobie na wszystko pozwolić" ${ }^{28}$, otwarcie manifestuje swoje odczucia i podziw wobec fizyczności mężczyzny: „mówiłam to kochankowi z Cholon, mówiłam również o jego ciele, o jego płci, o jego niewypowiedzianej gładkości [...]"29. Płeć i seksualność u Duras odczytana jest obrazoburczo, czego przykładem następujące zdanie: „Nieoczekiwanie widzę siebie jakby inną osobę - wyznaje bohaterka - jakbym widziała kogoś z zewnątrz, gotową na przyjęcie wszystkich spojrzeń, puszczoną w obieg miejskiego ruchu ulicznego, w obieg pożądania” ${ }^{30}$. Kondycja kobiety wyraża „sprzeciw podważający purytańskie fundamenty modernité - «nowoczesności», czyli nowożytnej cywilizacji Zachodu, w imię [...] nieograniczonego wyzwolenia (libération) popędów (désir)"31. Posiadanie własnego ciała jawi się jako imperatyw, ponieważ „kobiety, pozbawione do niego dostępu, nie mogą w pełni rozpoznać i konstytuować własnej tożsamości”32.

Sytuacja ta wynikała z hierarchii społecznej, w której główną pozycję zajmował mężczyzna. Oto portret ojca Simone de Beauvoir, który kreśli pisarka w Pamiętniku statecznej panienki (1958), gdzie snuje opowieść swojego życia w formie dziennika:

Osią jego osobistej moralności był kult rodzinny; kobieta, jako matka, była dlań świętością, wymagał od żon wierności, od młodych dziewczyn niewinności, ale mężczyznom przyznawał prawo do wielkich swobód, z czego wynikał pobłażliwy stosunek do kobiet tak zwanych lekkich. [...] W domu zdanie ojca było decydujące; matka, młodsza od niego o osiem lat, z własnej chęci we wszystkim była mu posłuszna: to on ją wtajemniczył w życie i w książki. „Kobieta jest tym co z niej robi mąż, to on ją powinien ukształtować" - mawiał często ${ }^{33}$.

24 Ibidem.

25 Ibidem, s. 94.

26 M. Duras, Kochanek, tłum. L. Kałuska, Wydawnictwo Literackie, Kraków 1989, s. 85.

27 Ibidem, s. 45.

28 Ibidem, s. 27.

29 Ibidem, s. 75.

30 Ibidem, s. 13.

31 J. Kowalski, M. i A. Loba, J. Prokop, Dzieje kultury francuskiej, PWN, Warszawa 2005, s. 450.

32 U.Śmietana, Od écriture féminine do „somatekstu”. Ciało w dyskursie feministycznym, „Przegląd Filozoficzno-Literacki” 2003, nr 1(3), s. 156.

33 S. de Beauvoir, Pamiętnik statecznej panienki, tłum. H. Szumańska-Grossowa, PIW, Warszawa 1960, s. 46. 
Pisarka przeciwstawia się mieszczaństwu, dbającemu wyłącznie o materialną niezależność, i jego ideałom, według których o wartości młodej kobiety decyduje proweniencja, posag oraz wygląd zewnętrzny, a nie wartość jednostki. Sama wyłamuje się z ograniczonego świata burżuazji:

Ze zgrozą zdałam sobie sprawę z mojej zależności. Nie tylko skazano mnie na wygnanie, ale nie dano mi możności walki z jałowością mego losu; moje czyny, gesty, słowa, wszystko było kontrolowane; szpiegowali moje myśli i jednym słowem mogli utrącić projekt, na którym zależało mi najbardziej, i nie miałam żadnego odwołania. [...] Stałam się inna i potrzebowałam innego świata dookoła siebie. [...] Przerażała mnie ta bierność. Pozostało mi tylko czekanie. Jak długo? Trzy lata, cztery lata? To długo, kiedy ma się osiemnaście lat. I jeśli je spędzę w więzieniu, związana, po wyjściu znajdę się znów tak samo sama, bez miłości, bez zapału, bez niczego. [...] Jeśli zostanę [...] nękana przez te same przesądy, te same troski, nigdy nie pójdę naprzód; nigdy nie stworzę żadnego dzieła ${ }^{34}$.

Pochodząca z mieszczańskiego środowiska Beauvoir wiele miejsca i uwagi poświęca życiu rodaczek w realiach patriarchalnego społeczeństwa. Czerpiąc z własnej biografii, przedstawia bolączki i nadzieje codziennej egzystencji kobiet: „W rzeczywistości nie poddawałam się nikomu: byłam i miałam pozostać na zawsze swoim jedynym władcą" ${ }^{35}$. Zależna od konwenansów i opinii publicznej, za wszelką cenę szuka nowych wyzwań: „Podporządkowana prawom, powagom, [...] lubiłam jednak wszystko, co było nowe, szczere, spontaniczne”" ${ }^{36}$ „upajałam się obietnicami przyszłości” ${ }^{37}$. Odrzuca en bloc instytucje, zwłaszcza małżeństwo: „[n]ieskończenie bardziej podobała mi się perspektywa pracy zawodowej od perspektywy małżeństwa; pozwalała na różne nadzieje"38 - wspomina Beauvoir.

W taki sposób autorka opisuje swój stosunek do małżeństwa z Sartre’em:

Myśl o małżeństwie w ogóle nie przychodziła nam do głowy. W zasadzie była nam przykra. [...] nasz anarchizm [...] nakazywał nam odrzucić ingerencję społeczeństwa w nasze sprawy prywatne. Byliśmy przeciwnikami instytucji, bo tłumią one wolność, i przeciwnikami burżuazji, od której instytucje pochodziły. [...] konwencja [...] była nam wstrętna ${ }^{39}$.

Beauvoir realizowała swój ideał emancypacji. Podobnie jak jej partner, była wyczulona "na każde usiłowanie zmierzające do lepszego poznania ludzi i obrony ich wolności. [...] Pochwala[ła] wysiłek zmierzający do wyzwolenia człowieka ze społecznego konformizmu i oswobodzenia od przyrody przez danie mu władzy nad własnym ciałem - zwłaszcza płodzenie dzieci nie powinno być uleganiem koniecz-

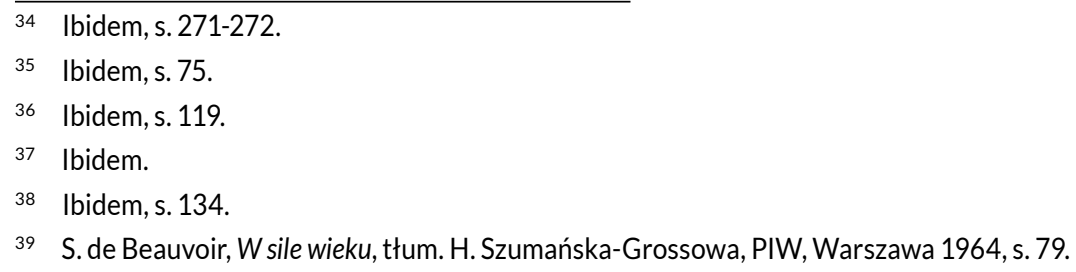


Od buntu do wyzwolenia. Image kobiety nieobyczajnej... From Rebellion to Liberation: The Image of an Ill-Mannered Woman...

ności, lecz własnym wyborem"40, gdyż „rodzenie dzieci nie jest jedynym przeznaczeniem kobiety" ${ }^{\prime 1}$. Wypowiadając się na temat obyczajowości, która zdecydowanie ograniczała kobiety, stwierdza: „Nie zależało mi na szacunku społeczeństwa. [...] Ale w wypadkach, w których dawało się rozdzielić miłość i małżeństwo, miłość, moim zdaniem, zdecydowanie zasługiwała na pierwszeństwo"42.

Analiza sytuacji kobiety - „niewolnicy i zwierciadła mężczyzny”43 dowodzi publicznej aprobaty tego stanu rzeczy, istnienia męskiej dominacji4 ${ }^{4} \mathrm{i}$ instytucjonalizacji praw męża, który akceptował takie formy niesprawiedliwości jak: przemoc, gwałt, wykorzystanie seksualne, pracę fizyczną ponad miarę itp. Spostrzeżenia pisarki prowadzą do konkluzji, iż w planie indywidualnym kobiety najważniejszą rzeczą jest odmowa małżeństwa, a tym samym brak przyzwolenia na uległość. Piętnuje cyniczną dwulicowość środowiska, które ceni wartości V Republiki i „katolicki[e] przesąd[y]”45. Priorytety swojego działania określa słowami: „zarabiać, wychodzić, przyjmować [gości], pisać, być wolną"46, co w oczywisty sposób przeciwstawia się wizji społeczeństwa, które „szano[wało] tylko kobiety zamężne”47 i uznawało „za rzecz niestosowną, by młoda panienka studiowała na serio, [gdyż] zdobycie zawodu było deklasacją" ${ }^{\prime}$. We wspomnieniach Beauvoir - „rozpustnic[y] o intelektualnych zamiłowaniach [...]"49 - pobrzmiewa ideał nieskrępowanej wolności, który wpisuje się w założenia egzystencjalistycznej filozofii: „Nie żałowałam, że jestem kobietą; przeciwnie, czerpałam dużo zadowolenia z tego faktu. Moje wychowanie przekonało mnie o intelektualnej niższości mojej płci"50 - wspomina autorka. Podobnie jak jej literackie bohaterki, jest gorącą orędowniczką równouprawnienia płci:

Chciałam, żeby dla męża i żony wszystko było wspólne; każde miało wobec drugiego spełniać rolę doskonałego świadka [...] wtedy wyjdę za mąż, kiedy spotkam doskonalszego ode mnie, takiego, jak ja, sobowtóra. [...] będę miała zawód, będę pisała, będę miała życie osobiste; nie miałam zamiaru być tylko towarzyszką mężczyzny [...].Cztery albo pięć lat studiów, a potem całe życie, które ukształtuję własnymi rękami ${ }^{51}$.

\footnotetext{
40 Ibidem, s. 135.

41 lbidem, s. 165.

42 S. de Beauvoir, Pamiętnik statecznej..., s. 421.

43 S. de Beauvoir, Druga płeć, tłum. M. Leśniewska, G. Mycielska, t. 1, Wydawnictwo Literackie, Kraków 1972, s. 18.

44 P. Bourdieu, Męska dominacja, tłum. L. Kopciewicz, Oficyna Wydawnicza, Warszawa 2004.

45 S. de Beauvoir, Druga płeć..., s. 143.

46 Eadem, Pamiętnik statecznej..., s. 411.

47 Ibidem, s. 423.

48 Ibidem, s. 421.

49 S. de Beauvoir, Siłą rzeczy, tłum. J. Pański, t. 2, PIW, Warszawa 1967, s. 425.

50 Eadem, Pamiętnik statecznej..., s. 382.

51 Ibidem, s. 187, 217.
} 
Zachowanie jednostki, pojmowane jako „indywidualna rzeczywistość”, związane jest z potwierdzeniem własnej tożsamości, sprzeciwem wobec wykluczenia społecznego. Gra ono niezwykle istotną rolę w określeniu własnej wartości. Beauvoir - jak pisze w jednym z tomów pamiętników W sile wieku - „[o]drzuciła moralność konwencjonalną i wszystkie inne, powołujące się na wieczność [...]"52, uważając wolność za „fundament wszelkiej ludzkiej wartości, [...] jedyny cel, jaki może usprawiedliwiać przedsięwzięcia ludzi” ${ }^{53}$. W kwestii erotyki wyznaje, iż

nie chciała [...], żeby miłość przybierała postać czynności zaplanowanej, [...] ale żeby była wolna, a nie postanowiona z góry [odrzucając] uleganie pragnieniom wbrew chęci [i] trzeźwe organizowanie rozkoszy. Radość miłosna miała być tak nieunikniona i nieprzewidziana jak fala morska [...] $]^{54}$.

Ta perspektywa pozwala Beauvoir uznać cielesność za upośledzenie kobiety, które w znaczący sposób przyczynia się do ograniczenia jej potencjału w wielu dziedzinach życia. Z tego powodu pisarka zaleca świadome planowanie rodziny, rozwój antykoncepcji, prawo kobiet do przerywania niechcianej ciąży, podkreślając brak związku między macierzyństwem a małżeństwem ${ }^{55}$, gdyż „wolność kobiety zaczyna się od brzucha"56. Jako zwolenniczka wolnych związków gorszy poglądami na temat małżeństwa, świadomego macierzyństwa, życia erotycznego. Ikona feminizmu uważa, że kobiety - „wasalk[i] płci mocnej”57 - mają mniejsze niż mężczyźni możliwości samorozwoju. Ci ostatni bowiem narzucają kobietom swoje wartości i, nawet mając wiele sympatii dla kobiet, nigdy nie zrozumieją ich położenia. Aby zmienić, a przynajmniej złagodzić istniejący stan rzeczy, Beauvoir proponuje modyfikację stosunków rodzinnych, równouprawnienie kobiet i mężczyzn, ujednolicenie systemów edukacyjnych dla obu płci, aktywizację zawodową kobiet. Tak oto wyjaśnia swoją decyzję:

jedną z ról uprzywilejowanych przeznaczyłam kobiecie, ponieważ bardzo wiele z tego, co chciałam powiedzieć, związane było z jej sytuacją. [...] kobieta, której powołaniem i zawodem jest pisanie, stanowi znacznie bardziej niż mężczyzna przypadek wyjątkowy ${ }^{58}$.

Dla autorki tradycyjna, patriarchalna forma małżeństwa o spolaryzowanych rolach obu partnerów była nie do przyjęcia, gdyż uniemożliwiała kobiecie pełną

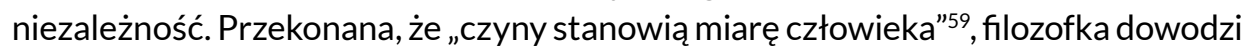

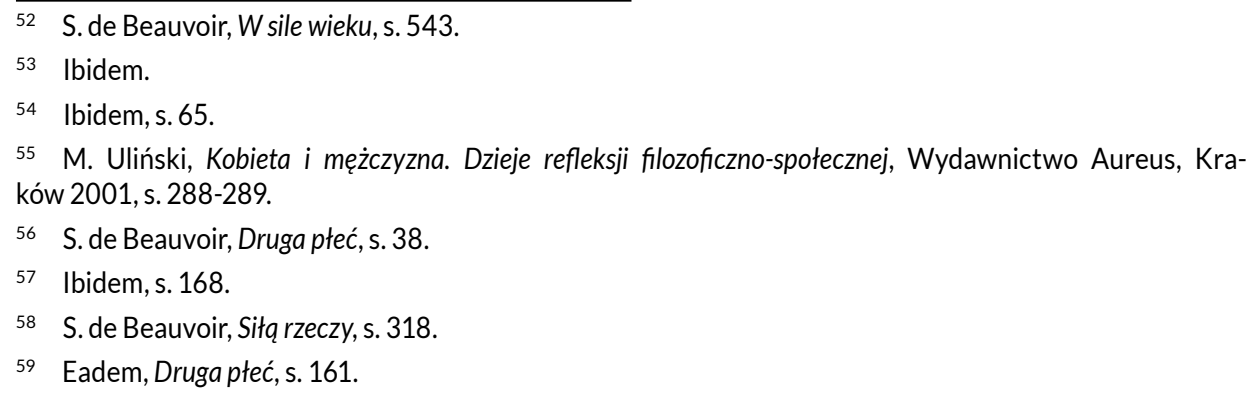


Od buntu do wyzwolenia. Image kobiety nieobyczajnej... From Rebellion to Liberation: The Image of an III-Mannered Woman...

w Drugiej płci, stanowiącej jeden z głównych punktów odniesienia refleksji nad egzystencją kobiety w dziejach cywilizacji i w kulturze współczesnej oraz najbardziej feministyczny utwór w jej dorobku: „Jak długo kobieta jest pasożytem, tak długo nie może uczestniczyć w wypracowaniu lepszego świata"60. I uważa pracę za szansę na samorealizację, swoiste wyzwolenie kobiety, przeciwstawiając się dobitnie bierności i konformizmowi. Kreuje w ten sposób antropologiczny ideał filozofii wolności, implikujący apoteozę aktywności, osiągnięć twórczych i kariery zawodowej:

Nie godziłam się, by jedno z dwojga małżonków miało prawo „zdradzać” drugie: jeśli przestali sobie odpowiadać, powinni się rozstać. Irytowałam się, kiedy ojciec upoważniał męża do „przelotnych romansików”. Nie byłam feministką [...] Ale dla mnie mężczyźni i kobiety byli ważni w jednakowym stopniu i żądałam ścisłej między nimi wzajemności. [...] pustota związków, miłostek, cudzołóstw mieszczańskich była dla mnie obrzydliwa. [...] Rozpowszechniona obecnie moralność erotyczna oburzała mnie i przez swoją pobłażliwość, i przez swoją surowość równocześnie ${ }^{61}$.

Pamiętajmy, że we Francji kobiety zamężne dopiero w 1965 r. zostały uwolnione od opieki i władzy męża, a pięć lat później z prawa francuskiego zniknęło określenie chef de famille. W 1957 r. zniesiono w tym kraju przepis, według którego żona nie mogła pracować zawodowo wbrew woli męża, a w 1985 r. wprowadzono równouprawnienie małżonków w zarządzaniu majątkiem. Jeśli chodzi o dostęp do wiedzy, długo zabraniano kobietom studiowania. Musiały one także stoczyć batalię o nadanie im praw wyborczych.

Konflikt między mieszczańską obyczajowością a emancypacją kobiety przedstawia także Françoise Sagan w powieści Witaj smutku (1954), która ukazuje portret inteligenckiej, bogatej młodzieży lat 50. XX w., przeżywającej dramat „inicjacyjny" społeczeństwa konsumpcyjnego. Warto zauważyć, że sfera obyczajów uległa w drugiej połowie XX stulecia wielkim zmianom. Zniknął stereotyp kobiety jako istoty słabej i delikatnej. Za pomocą kreacji protagonistki Cecylii pisarka koncentruje się na odmalowaniu wizerunku „amoralnej” młodej kobiety, która bulwersuje otoczenie swoim modus operandi, uważając, że "ma o wiele więcej zdolności do tego, żeby całować się z chłopcem w słońcu, niż żeby zrobić dyplom"62. Jej zachowanie uchodzi za skandalizujące, podobnie jak bezpardonowy sposób wypowiedzi: „Nie lubiłam młodzieży. O wiele bardziej interesowali mnie przyjaciele ojca, mężczyźni pod czterdziestkę, którzy prawili mi komplementy, słodkie słówka i okazywali czułość ojca i czułość kochanka"63. Bohaterka Sagan nie znajduje zadowolenia nawet w wyrafinowanym estetyzowaniu erotyki:

\footnotetext{
60 Eadem, Druga płeć, t. 2, s. 425.

61 S. de Beauvoir, Pamiętnik statecznej..., s. 245.

62 F. Sagan, Witaj smutku, tłum. A. Gostyńska i J. Olędzka, Wydawnictwo „Iskry”, Warszawa 1957, s. 45.

63 Ibidem, s. 10.
} 
Powtarzałam sobie z upodobaniem lapidarne sformułowania, między innymi następujące Oskara Wilde’a: „Grzech jest jedyną barwną plamą we współczesnym świecie”. Z absolutnym przekonaniem uważałam to zdanie za własne, z o wiele większym [...] niż gdybym je stosowała w praktyce. Sądziłam, że mogłabym się na nim wzorować, czerpać z niego natchnienie; ideałem wydawało mi się życie bezecne i podłe ${ }^{64}$.

Owa hedonistyczna filozofia życia tłumaczy jej „cyniczny i zblazowany stosunek do miłości"65:

Zawsze słyszałam, że miłość jest rzeczą łatwą; sama mówiłam o niej bez ogródek, z nieświadomością właściwą mojemu wiekowi [...] Nie wiem czy to, co czułam - wyzna Cecylia - dla [Cyryla] wtedy, to była miłość - nigdy nie byłam zbyt stała i nie zależy mi na tym, aby uważać się za inną, niż jestem [... $]^{66}$.

Dorastająca bohaterka to wyjątkowa i oryginalna postać, która prowadzi odmienny tryb życia i manifestuje swoją niezależność, „bardziej niż wszystkiego boi się nudy, spokoju. Aby osiągnąć spokój wewnętrzny, potrzebuje [...] podniet zewnętrznych"67. Potrafi odważnie narzucić własną wizję świata, swoje przekonania, odżegnując się od stereotypu istoty słabej i delikatnej. Wyzwolona z ciasnego gorsetu obyczajów i konwenansów, kobieta szokuje eksponowaniem cielesności, świadoma jest jednak znaczenia swojego rozwoju: „O ile dotychczas szukałam rekompensaty w dziedzinie uczuć, o tyle teraz chciałam wyżyć się w pracy zawodowej”68. Tym samym podkreśla, cytując autorów Dziejów kultury francuskiej, „potrzeb[ę] większej podmiotowości, większego udziału osobowości [...] zwiększenie poczucia relatywności osiągnięć nowoczesnej cywilizacji, styl bycia «na luzie» [...], ale także gorycz klęski marzeń [...] młodości [...]"69.

Powieści będące przedmiotem analizy przedstawiają model kobiety wyzwolonej, a tym samym nieobyczajnej, ukazują ewolucję jej samoświadomości, jaka dokonała się w XX w., kiedy opuszczała ona dom, by móc zrealizować się w pracy, odrzucając ówcześnie aprobowany w społeczeństwie wizerunek posłusznej, wzorowej żony i matki. Kobieta nie jest ani przewodniczką mężczyzny, ani jego służącą, ale samodzielną istotą, jednym z głównych aktorów życia społecznego, świadomą swojej wartości. Pisarstwo Colette, Beauvoir, Sagan, Duras poprzez nowatorstwo obyczajowe, podejmowanie kwestii tożsamości płciowej podważa stereotypy utrwalające nierówności istniejące między płciami oraz dominację męską w sferze prywatnej i publicznej. Zmienia ono także tradycyjny sposób przedstawiania kobiety w litera-

\footnotetext{
64 Ibidem, s. 15-16.

65 Ibidem, s. 15.

66 Ibidem, s. 50.

67 Ibidem, s. 64.

68 F. Sagan, Pewien uśmiech, tłum. A. Gostyńska, Książnica, Katowice 2003, s. 92.

69 J. Kowalski, M. i A. Loba, J. Prokop, op. cit., s. 495-496.
} 
Od buntu do wyzwolenia. Image kobiety nieobyczajnej... From Rebellion to Liberation: The Image of an III-Mannered Woman...

turze, kreując nowy typ bohaterki - atrakcyjnej i odważnie kierującej swoim życiem, która uwodzi, walcząc jednocześnie o własną autonomię. Przekonuje, że wartości kobiety nie determinuje jej stosunek do mężczyzny, że nie powinna zatracać się w miłości małżeńskiej czy macierzyńskiej, ale żyć dla siebie. Owa „wzniosła misja” uznana za jedynie słuszny cel nie pozwala jej bowiem być w pełni człowiekiem. Tylko wiara we własne siły, dążenia czy ideały pozwala kobiecie przestać być zwierciadłem mężczyzny i zdać sobie sprawę ze swoich możliwości. Świadome i szczere określenie własnych pragnień oraz ograniczeń prowadzi do wyzwolenia. Taki wizerunek kobiety jawi się jako projekcja tekstu kultury i nie przestaje fascynować do dziś.

Proza wymienionych autorek potwierdza tym samym istotne przeobrażenia, jakie zaszły w ubiegłym wieku między mieszczańską obyczajowością a emancypacją kobiety europejskiej w zakresie jej edukacji, świadomości i oczekiwań, na co zwraca uwagę badaczka literatury Béatrice Didier ${ }^{70}$. Modyfikuje bowiem ustaloną od wieków wizję stosunków kobieta-mężczyzna. Poszukiwanie wolności manifestujące się poprzez nienormatywne zachowania utożsamiane bywa z zerwaniem kontaktów z własnym otoczeniem, ucieczką w inną rzeczywistość, walką z konserwatywnymi i patriarchalnymi regułami, niezgodą na podwójne standardy fasadowej moralności. Ogromne znaczenie ma w tym kontekście traktowanie kobiety jako obiektu seksualnego, które zmienia - paradoksalnie in plus - jej samoocenę, wpisując się w dyskusję na temat habitusu w rozumieniu francuskiego socjologa Pierre'a Bourdieu ${ }^{71}$. Kobieta jest dumna ze swojego ciała, nie potrzebuje społecznej aprobaty, gardzi bezpieczeństwem i stabilizacją.

Aktywny sposób uczestnictwa kobiet w procesie samowyzwolenia dowodzi, że procesy liberalizacji i rozwoju kultury implikują zmianę miejsca kobiety w społeczeństwie, w którym definitywnie przestaje ona funkcjonować wyłącznie w relacji do mężczyzny. Analizowana w tym aspekcie „rola [kobiety] polega - jak trafnie zauważa Magdalena Matysek-Imielnicka - na kontestowaniu porządku kulturowego, jest źródłem kreatywności podmiotu, pozwalającym mu przekraczać konwencje"72, stereotypy. Cytowane utwory poruszają szeroko rozumianą tematykę kobiecą, odzwierciedlającą polemikę na temat społecznego statusu kobiety, a tym samym jednego z głównych wyzwań XX w., tj. przyzwolenia na inność kobiety, destabilizacji pojęcia kobiecości. Nowy obraz kobiety nosi już ślady modernité, wyrażając jednocześnie swoisty „klimat umysłowej wolności [...], liberalizm [...] i atmosfer[ę] szerokiej swobody [...]"

\footnotetext{
70 B. Didier, L'écriture-femme, PUF, Paris 1981, s. 37.

71 P. Bourdieu, Dystynkcja. Społeczna krytyka władzy sądzenia, tłum. P. Biłos, Scholar, Warszawa 2005, s. 281.

72 M. Matysek-Imielnicka, Mitologie kobiecości, czyli o historycznym krzyku i milczeniu kobiety, w: B. Płonka-Syroka, K. Marchel (red.), Wykluczanie. Społeczno-kulturowe mechanizmy kreowania emocji, t. 2, Arboretum, Wrocław 2010, s. 167.

73 G. Duby, R. Mandrou, Historia kultury francuskiej, tłum. H. Szumańska-Grossowa, PWN, Warszawa 1965, s. 573.
} 


\section{Bibliografia}

Badinter E., L'Un est l'autre. Des relations entre hommes et femmes, Odile Jacob, Paris 1986.

Beauvoir S. de, Druga płeć, tłum. M. Leśniewska, G. Mycielska, t. 1-2, Wydawnictwo Literackie, Kraków 1972.

Beauvoir S. de, Pamiętnik statecznej panienki, tłum. H. Szumańska-Grossowa, PIW, Warszawa 1960.

Beauvoir S. de, Siłą rzeczy, tłum. J. Pański, t. 2, PIW, Warszawa 1967.

Beauvoir S. de, W sile wieku, tłum. H. Szumańska-Grossowa, PIW, Warszawa 1964.

Bogucka M., Gorsza płeć. Kobieta w dziejach Europy od antyku po wiek XXI, Wydawnictwo Trio, Warszawa 2005.

Bourdieu P., Dystynkcja. Społeczna krytyka władzy sądzenia, tłum. P. Biłos, Scholar, Warszawa 2005.

Bourdieu P., Męska dominacja, tłum. L. Kopciewicz, Oficyna Wydawnicza, Warszawa 2004.

Chaney L., Coco Chanel. Życie intymne, tłum. A. Gralak, A. Sak, Znak, Kraków 2012.

Colette S.-G., Klaudyna w szkole, tłum. K. Dolatowska, PIW, Warszawa 1958.

Colette S.-G., Kotka, tłum. H. Weissowa, Wydawnictwa Nowoczesne, Warszawa 1934.

Colette S.-G., Małżeństwo Klaudyny, tłum. K. Dolatowska, PIW, Warszawa 1958.

Didier B., L'écriture-femme, PUF, Paris 1981.

Duby G., Mandrou R., Historia kultury francuskiej, tłum. H. Szumańska-Grossowa. PWN, Warszawa 1965.

Duras M., Kochanek, tłum. L. Kałuska, Wydawnictwo Literackie, Kraków 1989.

Duras M., Tama nad Pacyfikiem, tłum. Z. Jaremko-Pytkowska, Czytelnik, Warszawa 1960.

Foucault M., Historia seksualności, tłum. B. Banasiak, T. Komendant, Czytelnik, Warszawa 2000.

Fromm E., Miłość, płeć i matriarchat, tłum. B. Radomska, G. Sowiński, Dom Wydawniczy Rebis, Poznań 1997.

Kowalski J., Loba M. i A., Prokop J., Dzieje kultury francuskiej, PWN, Warszawa 2005.

Lottman H., Colette. Największy skandal Belle Époque, tłum. J. Addeo-Bratkiewicz, Wydawnictwo Alfa, Warszawa 1999.

Matysek-Imielnicka M., Mitologie kobiecości, czyli o historycznym krzyku i milczeniu kobiety, w: B. Płonka-Syroka, K. Marchel (red.), Wykluczanie. Społeczno-kulturowe mechanizmy kreowania emocji, t. 2, Arboretum, Wrocław 2010.

Sagan F., Pewien uśmiech, tłum. A. Gostyńska, Książnica, Katowice 2003.

Sagan F., Witaj smutku, tłum. A. Gostyńska i J. Olędzka, Wydawnictwo „Iskry”, Warszawa 1957.

Śmietana U., Od écriture féminine do „somatekstu”. Ciało w dyskursie feministycznym, „Przegląd Filozoficzno-Literacki” 2003, nr 1(3).

Uliński M., Kobieta i mężczyzna. Dzieje refleksji filozoficzno-społecznej, Wydawnictwo Aureus, Kraków 2001. 